\title{
Translocation and enrichment of heavy metals in Brassica juncea grown in Paper mill effluent irrigated soil
}

\section{Chakresh Pathak*, A. K . Chopra, Sachin Srivastava and Deepika Thakur ${ }^{1}$}

Department of Zoology and Environmental Science, Gurukula Kangri University, Haridwar-249404 (Uttarakhand), India ${ }^{1}$ Department of Environmental Studies, Panjab University, Chandigarh, INDIA

*Corresponding author. E-mail: chakreshpathak@yahoo.co.in

Received:December 1, 2013; Revised received:D ecember 15, 2013; Accepted:D ecember 18, 2013

Abstract: The present study observed the accumulation of heavy metals in Brassica juncea irrigated with paper mill effluent (PME) and control Bore well water (BWW). The soil was treated to five rates of effluents viz. 10, 25, 50,75 and $100 \mathrm{ml} / \mathrm{Kg}$ soil. It was revealed $100 \%$ PME irrigation of soil increased $\mathrm{Pb}(+46.44 \%), \mathrm{Cr}(+83.21 \%), \mathrm{Ni}(+38.43 \%)$ and $\mathrm{Cd}(+78.92 \%)$. The enrichment factor (Ef) for $\mathrm{Cr}$ and $\mathrm{Cd}$ showed moderate enrichment with $10 \%$ to $75 \% \mathrm{PME}$ irrigated soil, except $\mathrm{Cr}$ (5.96) which showed significant enrichment with 100\% PME irrigated soil. Ef value for $\mathrm{Pb}$ and $\mathrm{Ni}$ showed deficiency to mineral enrichment with different concentrations of PME irrigated soil. The maximum accumulation of $\mathrm{Pb}(42.66 \pm 2.05 \mathrm{mg} / \mathrm{kg}), \mathrm{Cr}(39.80 \pm 5.95 \mathrm{mg} / \mathrm{kg}), \mathrm{Ni}(88.64 \pm 11.29 \mathrm{mg} / \mathrm{kg})$ and Cd $(5.85 \pm 0.29 \mathrm{mg} / \mathrm{kg})$ were recorded in leaves of $\mathrm{B}$. juncea, while that of $\mathrm{Pb}(43.85 \pm 3.46 \mathrm{mg} / \mathrm{kg}), \mathrm{Cr}(48.59 \pm 3.81 \mathrm{mg} / \mathrm{kg}), \mathrm{Cd}(6.74 \pm 1.22$ $\mathrm{mg} / \mathrm{kg})$ with $100 \%$ and $\mathrm{Ni}(74.93 \pm 2.54 \mathrm{mg} / \mathrm{kg})$ were recorded with $75 \%$ PME after 60 days in roots of the B. juncea. Ef value was found maximum for $\mathrm{Cr}(5.08)$ in leaves and for $\mathrm{Pb}(6.64)$ in roots, while the Translocation factor (Tf) was found maximum for $\mathrm{Pb}(2.45)$ in root of the crop irrigated with PME. The use of PME with proper dilution and with the metallic concentrations in permissible limit can be used as biofertigant for irrigation of $B$. juncea.

Keywords: Brassica juncea, Heavymetals, Enrichment factor, Translocation factor

\section{INTRODUCTION}

Waste water irrigation, solid waste disposal, sludge application, vehicular exhaust and industrial activities are the major sources of soil contamination with heavy metals (Gupta etal., 2010, Harmanescu et al. 2011, Chopra and Pathak, 2012). Long term irrigation with such effluents increases organic carbon content, heavy metal accumulation in soil and the chances of their entrance in food chain and that may ultimately cause significant bioaccumulation (Chopra et al., 2009). On the other hand, wastewater is also a resource that can be applied for productive uses as it contains nutrients that can be used for the cultivation of agricultural crops (Hati et al., 2007; Chandra et al., 2009; Rath et al., 2011). The excessive accumulation of heavy metals in agricultural soils through wastewater irrigation may not only result in soil contamination, but also affect food quality and safety (Hati et al., 2007; Bharagava et al., 2008; Chopra et al., 2009).

Pulp and paper mill is a major industrial sector utilizing a huge amount of lignocellulogic materials and water during the manufacturing process, and release chlorinated lignosulphonic acids, chlorinated resin acids, chlorinated phenols and chlorinated hydrocarbon in the effluent (Liss et al., 1997 and Singh, 2007). In India, there are 666 pulp ISSN : 0974-9411 (Print), 2231-5209 (Online) All Rights Reserved ๑ Applied and Natural Science Foundation www.ansfoundation.org and paper mills, out of which 632 mills are agro- based residue mills (Malla and Mohanty, 2005; Kumar and Chopra, 2012). They generate a huge amount of wastewater (black liquor) having high biological oxygen demand (BOD) and chemical oxygen demand (COD) (Mapanda et al., 2005; Kumar, 2010). These mills are highly water intensive, consuming 100-250 $\mathrm{m}^{3}$ freshwater/ ton paper and also generate the corresponding wastewater $75-225 \mathrm{~m}^{3}$ wastewater/ton paper (Thompson, 2001 and Tewari et al., 2009).

Irrigation of crops with effluents is a very common practice in India due to scarcity of water for irrigation (Sharma et al., 2007, Arora et al., 2008). The effect of effluents irrigation on various crops/vegetables has been studied to observe the concentration of accumulated metals to which human beings are exposed (Ismail et al., 2005, Singh and Kumar, 2006). Keeping this in view, the present study was carried out to investigate the translocation and enrichment of heavy metals in leafy vegetable, $B$. juncea after irrigation of soil with Paper mill effluent (PME).

\section{MATERIALS AND METHODS}

Experimental design: A field study experiment was conducted in the Experimental garden of the Department of Zoology and Environmental Sciences, Faculty of Life 
Sciences, Gurukula Kangri University Haridwar $\left(29^{\circ} 55^{\prime} 10.81^{\prime \prime} \mathrm{N}\right.$ and $\left.78^{\circ} 07^{\prime} 08.12^{\prime \prime} \mathrm{E}\right)$ during the period of November, 2010 to January, 2011. The poly bags (dia$30 \mathrm{~cm}$ ) were used for growing $B$. juncea. The pots were arranged in a completely randomized design with four replicates. Twenty four poly bags were filled with soil and used for the cultivation of $B$. juncea. The proper distance was maintained between each replicate $(30 \mathrm{~cm})$ between all treatments $(60 \mathrm{~cm})$ and plant to plant $(5 \mathrm{~cm})$ for the maximum performance of the crop. Each poly bag was made porous for aeration. The poly bags with $B$. juncea were given various treatments viz. 10, 25, 50, 75 and $100 \%$ of the Paper mill effluent (PME) and with Bore well water (BWW) taken as control, separately.

A nalysis of soil, leaves and roots of the crop: The soil samples were analyzed before and after irrigation of soil with PME and BWW, while B.juncea samples of leaves and roots were analyzed after irrigation of the soil and harvesting of the crop for heavy metals $(\mathrm{Pb}, \mathrm{Cr}, \mathrm{Cd}$ and $\mathrm{Ni}$ ) as per standard methods of APHA (2005) and Chaturvedi and Sankar (2006).

The samples of soil as well as the leaves and roots were dried separately in the air at room temperature and sieved through a $2 \mathrm{~mm}$ sieve. Samples were digested in nitric acid $\left(\mathrm{HNO}_{3}\right)$ and perchloric acid $\left(\mathrm{HClO}_{4}\right)$ acid as per the method described in AOAC (Association of Official Analytical Chemists, 1990). After digestion, all samples were filtered through Whatmann No. 42 filter paper and in each case volume was made with $50 \mathrm{ml}$. The heavy metals $\mathrm{Pb}, \mathrm{Cr}, \mathrm{Cd}$ and $\mathrm{Ni}$ were determined in the digested aliquot by Atomic Absorption Spectrophotometer (AAS) (Make-ECIL, Model No. 4129) using a specific lamp of particular metal using appropriate drift blank.

Data analysis: The heavy metal contents in both the $B$. juncea and adjoining soil were expressed as means and standard deviation of six replicates calculated in Microsoft Office Excel (2007) and Axum50.

\section{RESULTS AND DISCUSSION}

Heavy metals of soil irrigated with $P M E$ : The mean \pm SD values of heavy metals $(\mathrm{Cd}, \mathrm{Ni}, \mathrm{Pb}$ and $\mathrm{Cr}$ ) of the soil before and after irrigation with different concentrations of PME viz. 10\%, 25\%, 50\%, $75 \%$ and $100 \%$ are given in the Table 1.

In the present study, maximum concentrations of the heavy metals were recorded for $\mathrm{Pb}(17.40 \pm 0.78 \mathrm{mg} / \mathrm{kg})$, $\mathrm{Cr}(32.02 \pm 1.18 \mathrm{mg} / \mathrm{kg}), \mathrm{Ni}(67.02 \pm 1.46 \mathrm{mg} / \mathrm{kg})$ and $\mathrm{Cd}$ $(6.35 \pm 0.49 \mathrm{mg} / \mathrm{kg})$ with $100 \%$ PME irrigated soil and minimum concentrations were recorded for $\mathrm{Pb}$ $(10.89 \pm 0.45 \mathrm{mg} / \mathrm{kg}), \mathrm{Cr}(13.76 \pm 0.57 \mathrm{mg} / \mathrm{kg}), \mathrm{Ni}(45.28 \pm 1.14$ $\mathrm{mg} / \mathrm{kg})$ and $\mathrm{Cd}(2.77 \pm 0.43 \mathrm{mg} / \mathrm{kg})$ with $10 \%$ PME irrigated soil in comparison to control.

There was a remarkable increase of $60.94 \% \mathrm{Cr}$ with $10 \%$, $68.52 \%$ with $25 \%, 75.55 \%$ with $50 \%, 80.27 \%$ with $75 \%$,
$83.21 \%$ with $100 \%$ and of $51.71 \%$ Cd with $10 \%, 64.45 \%$ with $25 \%, 69.57 \%$ with $50 \%, 74.40 \%$ with $75 \%$ and $78.92 \%$ with $100 \%$ concentration of PME irrigated soil in comparison to control. It may likely occur due to the presence of significant quantity of heavy metals at higher concentrations of PME. During the present study heavy metals contents were found minimum at lower concentrations (10 to 50\%) and maximum at higher concentrations ( 75 to $100 \%$ ) of PME irrigated soil. There was much variation in the metal contents of soil irrigated different concentration of PME.This was likely due to dilution of the PME, which minimizes the quantity of heavy metals in the effluent irrigated soil. The present data revealed that the level of heavy metals in soil increased as per dilution quantity of PME. In the present study heavy metal content such as $\mathrm{Pb}(17.40 \pm 0.78 \mathrm{mg} /$ $\mathrm{kg}), \mathrm{Cr}(32.02 \pm 1.18 \mathrm{mg} / \mathrm{kg}), \mathrm{Ni}(67.02 \pm 1.46 \mathrm{mg} / \mathrm{kg})$ and $\mathrm{Cd}$ $(6.35 \pm 0.49 \mathrm{mg} / \mathrm{kg})$ with $100 \%$ PME irrigated soil was higher than those reported by Pathak et al. (2013) for $\mathrm{Cr}$ $(29.53 \pm 3.33 \mathrm{mg} / \mathrm{kg})$ and $\mathrm{Cd}(6.11 \pm 1.74 \mathrm{mg} / \mathrm{kg})$ in $100 \%$ PME irrigated soil, except $\mathrm{Ni}(206.18 \pm 13.44 \mathrm{mg} / \mathrm{kg})$ in PME irrigated soil at Haridwar, whereas Sinha et al. (2008) found $\mathrm{Fe}(14,285 \pm 1244 \mathrm{mg} / \mathrm{kg}), \mathrm{Cr}(197.76 \pm 12.83 \mathrm{mg} / \mathrm{kg})$ and $\mathrm{Zn}(104.91 \pm 0.97 \mathrm{mg} / \mathrm{kg})$ in soils treated with different tannery sludge applications.

$\mathrm{PME}$ irrigation increased $\mathrm{Pb}, \mathrm{Cr}, \mathrm{Cd}$ and $\mathrm{Ni}$ of the soil. As per Indian Standards (Awashthi, 2000), Pb, Cr and Ni were below the permissible limits while $\mathrm{Cd}$ was above the permissible limits except in case of 10\% PME irrigated soil. The concentration of $\mathrm{Pb}$ and $\mathrm{Cr}$ were below the permissible limits, while $\mathrm{Cd}$ and $\mathrm{Ni}$ in 100\% PME irrigated soil were above the permissible limits reported by KabataPendias and Pendias (1992).

Ef for soil irrigated with PME : In the present study the $\mathrm{EF}$ value of the $\mathrm{Pb}, \mathrm{Cr}, \mathrm{Cd}$ and $\mathrm{Ni}$ were found maximum for $\mathrm{Cr}$ (5.96) with 100\% PME irrigation and minimum for $\mathrm{Ni}$ (1.10) in 10\% PME irrigated soil. The Ef was found in the order of $\mathrm{Cr}$ (2.56) $>\mathrm{Cd}(2.07)>\mathrm{Pb}(1.17)>\mathrm{Ni}(1.10)$ for $10 \%, \mathrm{Cr}(3.18)>\mathrm{Cd}(2.81)>\mathrm{Pb}(1.33)>\mathrm{Ni}(1.14)$ for $25 \%$, $\mathrm{Cr}(4.09)>\mathrm{Cd}(3.29)>\mathrm{Pb}(1.49)>\mathrm{Ni}(1.24)$ for $50 \%, \mathrm{Cr}$ (5.07) $>\mathrm{Cd}(3.91)>\mathrm{Pb}(1.69)>\mathrm{Ni}(1.40)$ for $75 \%$ and $\mathrm{Cr}$ (5.96) $>\mathrm{Cd}(4.74)>\mathrm{Pb}(1.87)>\mathrm{Ni}$ (1.62) for 100\% $\mathrm{PME}$ irrigated soil. The $\mathrm{Ef}$ value for $\mathrm{Cr}$ and $\mathrm{Cd}$ showed moderate enrichment with 10\%, 25\%, 50\% and 75\% PME irrigated soil, except $\mathrm{Cr}$ (5.96) which showed significant enrichment in $100 \% \mathrm{PME}$ irrigated soil. Ef value for $\mathrm{Pb}$ and $\mathrm{Ni}$ showed deficiency to mineral enrichment with 10\%, 25\%, 50\%, $75 \%$ and $100 \%$ PME irrigation. The Ef value of $\mathrm{Ni}$ for soil was lower than Ni (3.27) as reported by Pathak et al. (2013) for PME irrigated soil. Kumar and Chopra (2010) also reported more $\mathrm{Ef}$ for $\mathrm{Cr}$ (11.24), $\mathrm{Cd}$ (5.04) in soil irrigated with Sugar mill effluent.

Heavy metal s in leaves and root of $B$. juncea irrigated with PME: The metal concentrations in $B$. juncea roots/ 
Table 1. Heavy metals contents before and after irrigation with PME and BWW irrigated soil.

\begin{tabular}{|c|c|c|c|c|c|c|c|c|c|}
\hline \multirow[b]{2}{*}{ M etals } & \multirow{2}{*}{$\begin{array}{c}\text { Before } \\
\text { effluent } \\
\text { irrigation } \\
\end{array}$} & \multirow{2}{*}{$\begin{array}{c}\text { After } \\
\text { BWW } \\
\text { Irrigation }\end{array}$} & \multicolumn{5}{|c|}{ After effluent irrigation } & \multirow{2}{*}{ Limit(a) } & \multirow{2}{*}{ Limit(b) } \\
\hline & & & $10 \%$ & $25 \%$ & $50 \%$ & $75 \%$ & $100 \%$ & & \\
\hline $\mathrm{Pb}$ & 8.57 & $9.32 \pm 0.73$ & $\begin{array}{l}10.89 \pm 0.45 \\
(+14.42 \%)\end{array}$ & $\begin{array}{l}12.37 \pm 0.85 \\
(+24.67 \%)\end{array}$ & $\begin{array}{c}13.92 \pm 0.48 \\
(+33.06 \%)\end{array}$ & $\begin{array}{l}15.71 \pm 0.45 \\
(+40.68 \%)\end{array}$ & $\begin{array}{l}17.40 \pm 0.78 \\
(+46.44 \%)\end{array}$ & $250-500$ & 50 \\
\hline $\mathrm{Cr}$ & 12.34 & $12.38 \pm 0.72$ & $\begin{array}{l}13.76 \pm 0.57 \\
(+60.94 \%)\end{array}$ & $\begin{array}{l}17.07 \pm 1.44 \\
(+68.52 \%)\end{array}$ & $\begin{array}{l}21.99 \pm 1.74 \\
(+75.55 \%)\end{array}$ & $\begin{array}{c}27.24 \pm 2.43 \\
(+80.27 \%)\end{array}$ & $\begin{array}{c}32.02 \pm 1.18 \\
(+83.21 \%)\end{array}$ & $\mathrm{n} / \mathrm{a}$ & 100 \\
\hline $\mathrm{Ni}$ & 43.26 & $41.27 \pm 3.58$ & $\begin{array}{c}45.28 \pm 1.14 \\
(+8.87 \%)\end{array}$ & $\begin{array}{r}47.10 \pm 2.49 \\
(+12.39 \%)\end{array}$ & $\begin{array}{l}51.12 \pm 1.65 \\
(+19.27 \%)\end{array}$ & $\begin{array}{l}57.65 \pm 1.02 \\
(+28.41 \%)\end{array}$ & $\begin{array}{l}67.02 \pm 1.46 \\
(+38.43 \%)\end{array}$ & $75-150$ & 30 \\
\hline $\mathrm{Cd}$ & 3.24 & $2.09 \pm 0.46$ & $\begin{array}{l}2.77 \pm 0.43 \\
(+51.71 \%)\end{array}$ & $\begin{array}{l}3.76 \pm 0.98 \\
(+64.45 \%)\end{array}$ & $\begin{array}{l}4.40 \pm 0.17 \\
(+69.57 \%)\end{array}$ & $\begin{array}{l}5.23 \pm 0.42 \\
(+74.40 \%)\end{array}$ & $\begin{array}{l}6.35 \pm 0.49 \\
(+78.92 \%)\end{array}$ & $3-6$ & 1 \\
\hline
\end{tabular}

(a) Source: Awashthi (2000); (b)Source: Kabata-Pendias and Pendias (1992), n/a - not avialable

shoots, Ef value and Tf for B. juncea are given in Fig 1and 2 .

The maximum heavy metals contents was found for $\mathrm{Pb}$ $(42.66 \pm 2.05 \mathrm{mg} / \mathrm{kg}), \mathrm{Cr}(39.80 \pm 5.95 \mathrm{mg} / \mathrm{kg}), \mathrm{Ni}(88.64 \pm 11.29$ $\mathrm{mg} / \mathrm{kg})$ and $\mathrm{Cd}(5.85 \pm 0.29 \mathrm{mg} / \mathrm{kg})$ in leaves, while that of $\mathrm{Pb}(43.85 \pm 3.46 \mathrm{mg} / \mathrm{kg}), \mathrm{Cr}(48.59 \pm 3.81 \mathrm{mg} / \mathrm{kg}), \mathrm{Cd}$ $(6.74 \pm 1.22 \mathrm{mg} / \mathrm{kg})$ in root of $B$. juncea irrigated with $100 \%$ PME concentrations. Ni was recorded maximum $(74.93 \pm 2.54 \mathrm{mg} / \mathrm{kg})$ in roots of $\mathrm{B}$. juncea irrigated with $75 \%$ PME concentration.

The concentrations of $\mathrm{Pb}, \mathrm{Cr}, \mathrm{Cd}$ and $\mathrm{Ni}$ in edible parts of $B$. juncea were above the permissible limits of FAO/WHO standard (Codex Alimentarious Commission, 1984) and Indian Standard (Awashthi, 2000) except Cr with 10\% and 25\% PME irrigation. The metal accumulation in the PME irrigated $B$. juncea showed that the concentration of $\mathrm{Pb}, \mathrm{Cr}, \mathrm{Ni}$ and $\mathrm{Cd}$ increase in the soil as per dilution, because the maximum contents of heavy metals increased up to $100 \%$ PME concentration. This might be due to increase in concentration of organic and inorganic materials, which are mainly responsible for the increase in the contents of metals in PME. From the above scenario based on $10 \%, 25 \%, 50 \%, 75 \%$ and $100 \%$ effluent irrigation, it was observed that the metal status increased to their higher concentrations in soil irrigated with PME as also reported by Kumar et al. (2010). Similar observations of higher metal accumulation have been reported by Kumar and Chopra (2012) for Trigonella foenum-graecum L. (Fenugreek) plants irrigated with Distillery effluent (DE).

$E f$ for $B$. juncea irrigated with PM E: The Ef values of different metals indicated that root to shoot translocation of metals in B. juncea was quite higher after 60 days of growth period, showing their ability to translocate metals from the root to the shoot, or to compartmentalize it in order to continue the absorption of metals from the growth media. The EF values for leaves of $B$. juncea were in the order of $\mathrm{Cd}(2.37)>\mathrm{Cr}(1.56)>\mathrm{Ni}(1.45)>\mathrm{Pb}(1.20)$ in $10 \%$, $\mathrm{Cd}(2.58)>\mathrm{Pb}(2.09)>\mathrm{Cr}(2.12)>\mathrm{Ni}(1.68)$ in $25 \%, \mathrm{Cr}$ $(3.10)>\mathrm{Cd}(2.75)>\mathrm{Pb}(2.74)>\mathrm{Ni}(2.00)$ in $50 \%, \mathrm{~Pb}(3.46)$ $>\mathrm{Cr}(3.46)>\mathrm{Cd}(2.68)>\mathrm{Ni}(2.35)$ in $75 \%, \mathrm{~Pb}(5.56)>\mathrm{Cr}$ $(5.08)>\mathrm{Cd}(4.37)>\mathrm{Ni}$ (2.95) in 100\% PME irrigated soil. In case of $10 \% \mathrm{PME}$ irrigated $\mathrm{B}$. juncea leaves, Ef values for $\mathrm{Pb}, \mathrm{Cr}$ and $\mathrm{Ni}$ showed the minimal enrichment, while Cd showed moderate enrichment in 10\% PME irrigated soil. In case of $25 \% \mathrm{PME}$ irrigated $\mathrm{B}$. juncea leaves $\mathrm{Pb}, \mathrm{Cr}$ and $\mathrm{Cd}$ showed moderate enrichment and $\mathrm{Ni}$ showed the minimal enrichment. The Ef values with $50 \%, 75 \%$ and $100 \%$ PME irrigated B. juncea leaves for $\mathrm{Cr}, \mathrm{Cd}$ and $\mathrm{Ni}$ showed moderate enrichment except $\mathrm{Pb}$, which showed moderate enrichment with 50\%/75\% and significant enrichment with $100 \%$ PME irrigation.

According to enrichment categories in B. juncea leaves, the Ef values for $\mathrm{Cd}$ showed moderate enrichment with

Table 2. Heavy metals contents in leaves and roots of B. juncea grown in PME and BWW irrigated soil.

\begin{tabular}{|c|c|c|c|c|c|c|c|c|c|}
\hline \multirow[b]{2}{*}{ M etals } & \multirow{2}{*}{$\begin{array}{l}\text { Plant } \\
\overline{\text { p}} \text { arts }\end{array}$} & \multirow{2}{*}{$\begin{array}{c}\text { After } \\
\text { BWW } \\
\text { irrigation }\end{array}$} & \multicolumn{5}{|c|}{ After effluent irrigation } & \multirow[t]{2}{*}{ Limit(a) } & \multirow[t]{2}{*}{ Limit(b) } \\
\hline & & & $10 \%$ & $25 \%$ & $50 \%$ & $75 \%$ & $100 \%$ & & \\
\hline \multirow[t]{2}{*}{$\mathrm{Pb}$} & Leaves & $7.67 \pm 0.69$ & $9.21 \pm 0.55$ & $16.06 \pm 0.88$ & $20.99 \pm 0.52$ & $26.56 \pm 1.53$ & $42.66 \pm 2.05$ & 5 & 2.5 \\
\hline & Root & $6.60 \pm 0.72$ & $9.76 \pm 0.51$ & $19.51 \pm 1.04$ & $15.27 \pm 1.08$ & $23.04 \pm 6.34$ & $43.85 \pm 3.46$ & & \\
\hline \multirow[t]{2}{*}{$\mathrm{Cr}$} & Leaves & $13.35 \pm 1.12$ & $12.21 \pm 0.88$ & $16.64 \pm 0.45$ & $24.27 \pm 0.60$ & $27.13 \pm 3.23$ & $39.80 \pm 5.95$ & 5 & 20 \\
\hline & Root & $11.01 \pm 1.33$ & $13.49 \pm 0.91$ & $17.49 \pm 1.09$ & $29.90 \pm 2.96$ & $31.16 \pm 1.55$ & $48.59 \pm 3.81$ & & \\
\hline \multirow[t]{2}{*}{$\mathrm{Cd}$} & Leaves & $1.34 \pm 0.13$ & $3.17 \pm 0.55$ & $3.45 \pm 0.31$ & $3.68 \pm 0.41$ & $3.59 \pm 0.25$ & $5.85 \pm 0.29$ & 0.3 & 1.5 \\
\hline & Root & $1.35 \pm 0.17$ & $4.02 \pm 0.64$ & $4.34 \pm 0.86$ & $4.59 \pm 0.15$ & $6.01 \pm 0.72$ & $6.74 \pm 1.22$ & & \\
\hline \multirow[t]{2}{*}{$\mathrm{Ni}$} & Leaves & $30.06 \pm 1.39$ & $43.61 \pm 3.94$ & $50.46 \pm 1.52$ & $60.19 \pm 3.87$ & $70.67 \pm 6.01$ & $88.64 \pm 11.29$ & 20 & 1.5 \\
\hline & Root & $25.38 \pm 2.11$ & $45.88 \pm 2.32$ & $52.93 \pm 1.07$ & $62.69 \pm 3.08$ & $74.93 \pm 2.54$ & $51.78 \pm 4.10$ & & \\
\hline
\end{tabular}

(a) FAO/WHO standard (Codex Alimentarious Commission 1984) (b) Indian standard (Awashthi 2000). 


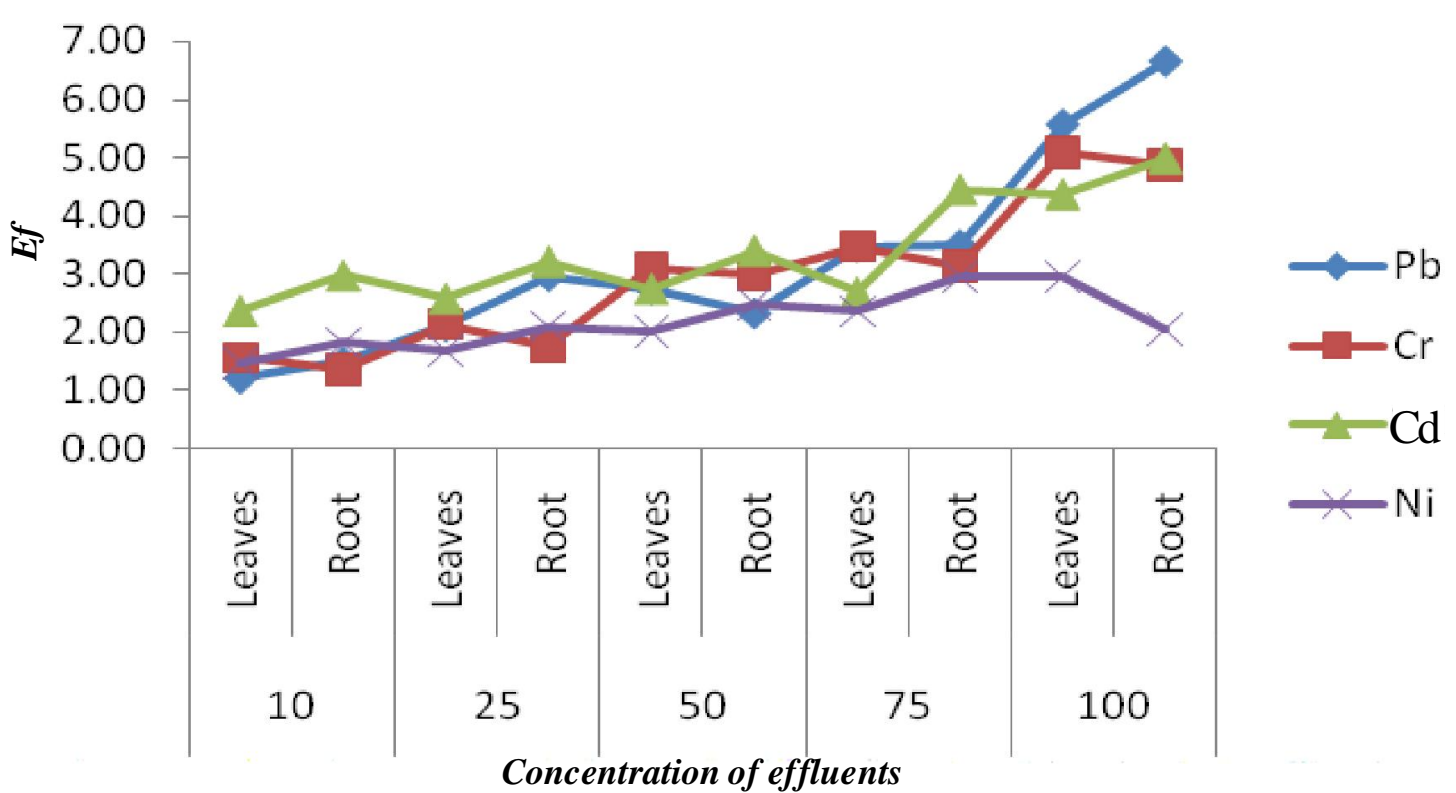

Fig. 1. Ef for leaves and root of $B$. juncea irrigated with PME.

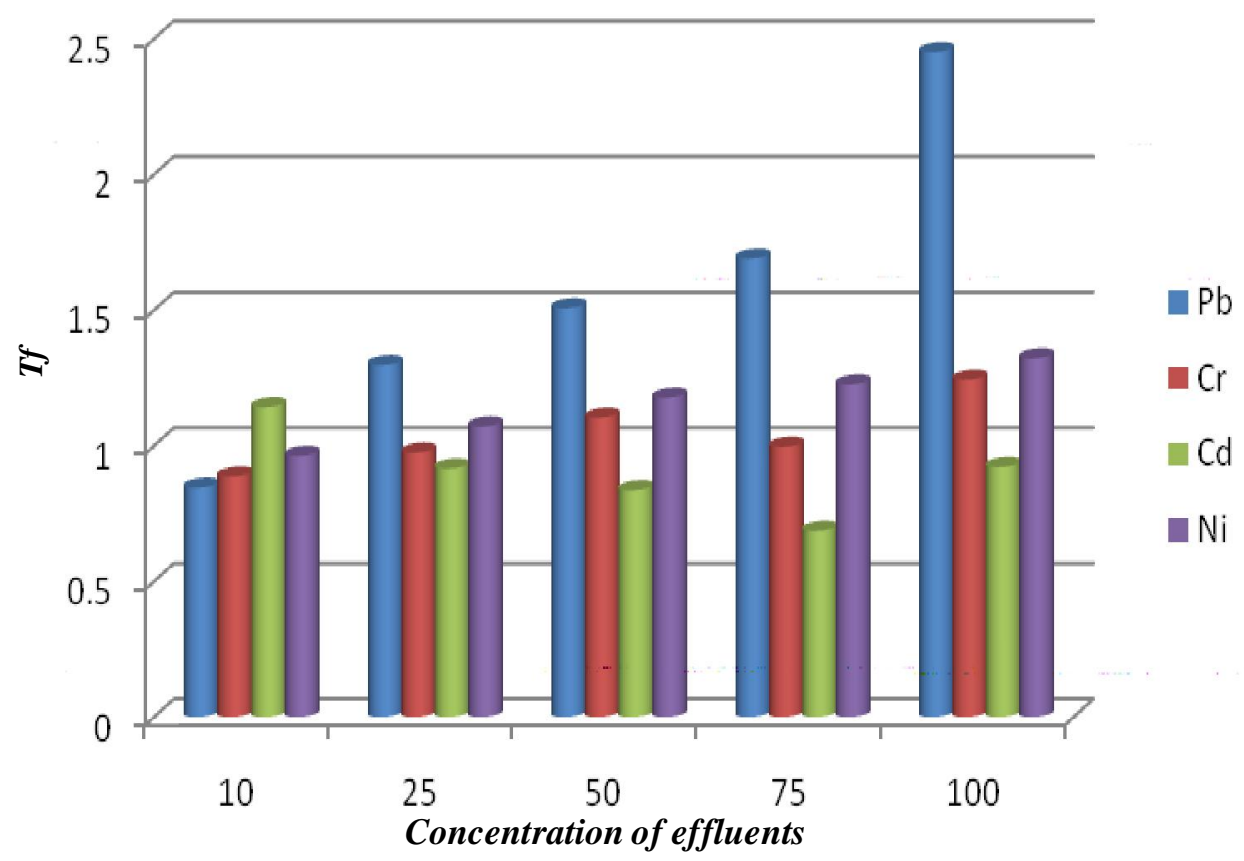

Fig. 2. Tf for $B$. juncea irrigated with PME.

all treatments and for $\mathrm{Pb}$ and $\mathrm{Cr}$, it showed moderate enrichment with $25 \%, 50 \%$ and $75 \%$ and significant enrichment with 100\% PME irrigation, while Ni showed moderate enrichment with $50 \%, 75 \%$ and $100 \%$ PME irrigation.

In root part of $B$. juncea, the Ef values were found in the order of $\mathrm{Cd}(2.97)>\mathrm{Ni}(1.81)>\mathrm{Pb}(1.48)>\mathrm{Cr}(1.35)$ in $10 \%$, $\mathrm{Cd}(3.22)>\mathrm{Pb}(2.96)>\mathrm{Ni}(2.09)>\mathrm{Cr}(1.75)$ in $25 \%, \mathrm{Cd}$ (3.40) $>\mathrm{Cr}(2.99)>\mathrm{Ni}(2.47)>\mathrm{Pb}(2.31)$ in $50 \%, \mathrm{Cd}(4.45)$ $>\mathrm{Pb}(3.49)>\mathrm{Cr}(3.11)>\mathrm{Ni}$ (2.95) in 75\%, $\mathrm{Pb}(6.64)>\mathrm{Cd}$ (4.99) $>\mathrm{Cr}(4.86)>\mathrm{Ni}$ (2.04) for B. juncea in 100\% PME irrigated soil. The Ef values with $10 \%$ PME irrigated $B$. juncea root showed minimal enrichment for $\mathrm{Ni}, \mathrm{Pb}, \mathrm{Cr}$ and moderate enrichment for $\mathrm{Cd}$. In case of $25 \% \mathrm{PME}$ irrigated $\mathrm{B}$. juncea root, $\mathrm{Cd}, \mathrm{Pb}$, and $\mathrm{Ni}$ showed moderate and $\mathrm{Cr}$ showed the minimal enrichment. The Ef values with 50\%, 75\% and 100\% PME irrigated B. juncea root for $\mathrm{Cr}, \mathrm{Cd}$ and $\mathrm{Ni}$ showed moderate enrichment except $\mathrm{Pb}$, which showed moderate enrichment with 50\%/75\% and significant enrichment category with 100\% PME irrigation. Among the various Ef values in B. juncea root, $\mathrm{Cd}$ showed moderate enrichment category in all treatments, $\mathrm{Cr}$ was found in moderate enrichment category with 50\% 75\% and 100\% PME irrigation, while $\mathrm{Ni}$ was in moderate enrichment category in $25 \%, 50 \%$, $75 \%$ and $100 \%$ PME irrigation. $\mathrm{Pb}$ was in moderate 
enrichment with $25 \%, 50 \%, 75 \%$ and significant enrichment with $100 \%$ irrigation after irrigation with PME. The present EF values of $\mathrm{Cr}$ (4.86) was lower than the values reported by Gupta et al. (2008) for $\mathrm{Cr}$ (7.58) in the tomato plants grown in the contaminated soil irrigated with sponge iron effluent and also lower than the values reported by Kumar and Chopra (2012) for Cr (21.4), Cd (16.5) in Trigonella foenum graecum plants irrigated with DE irrigated soil.

Tf for B. juncea irrigated with PME : Soil-to-plant transfer of heavy metals is one of the key components of human exposure to metals through food chain. Variations in $\mathrm{Tf}$ among different vegetables may be attributed to differences in the concentration of metals in the soil and to the differences in element-uptake by different vegetables (Cui et al., 2004; Zheng et al., 2007, Singh et al., 2010). The translocation process of metals from root to shoot includes long distance in xylem and storage in vacuoles of leaf cells and it is affected by several factors (Yang et al., 1997).

Among different PME concentration, maximum Tf value off 1.14 were observed for $\mathrm{Cd}$ with $10 \%, 1.30$ for $\mathrm{Pb}$ and 1.07 for $\mathrm{Ni}$ with $25 \%, 1.51$ for $\mathrm{Pb}, 1.10$ for $\mathrm{Cr}$ and 1.18 for $\mathrm{Ni}$ with $50 \%, 1.69$ for $\mathrm{Pb}$ and 1.23 for $\mathrm{Ni}$ with $75 \%, 2.45$ for $\mathrm{Pb}, 1.24$ for $\mathrm{Cr}$ and 1.32 for $\mathrm{Ni}$ was recorded with $100 \%$ in B. juncea grown in PME irrigated soil.

The present $\mathrm{Tf}$ values of $\mathrm{Cr}$ (1.24) was higher than that reported by Smical et al. (2008) for $\mathrm{Cr}(0.194)$, while the values of $\mathrm{Ni}$ and $\mathrm{Cd}$ were lower than that observed for $\mathrm{Ni}$ (0.827), Cd (0.996) in Spinach grown at wastewater irrigated soil (Singh et al., 2010). The higher translocation values for these metals from soil to plants indicated a strong accumulation of these metals by $B$. juncea.

\section{Conclusion}

It was concluded that PME irrigation increased $\mathrm{Pb}, \mathrm{Cr}$, $\mathrm{Cd}$ and $\mathrm{Ni}$ of the soil. As per Indian Standards, $\mathrm{Pb}, \mathrm{Cr}$ and $\mathrm{Ni}$ were below the permissible limit while $\mathrm{Cd}$ was above the permissible limit except in case of 10\% PME irrigation. The concentration of $\mathrm{Pb}$ and $\mathrm{Cr}$ was below the permissible limit while $\mathrm{Cd}$ and $\mathrm{Ni}$ were above the permissible limit. The level of metals except $\mathrm{Cr}$ in $\mathrm{B}$. juncea exceeded many folds as per FAO/WHO standard and Indian standards with $10 \%$ and $25 \%$ PME irrigation The maximumEf values were found for $\mathrm{Cr}$ (5.96), which showed significant enrichment in 100\% PME effluent irrigated soil. The maximum $\mathrm{Ef}$ value for $\mathrm{Pb}$ (5.56 in leaves and 6.64 in root) showed significant enrichment in $B$. juncea. Among the various $\mathrm{Tf}$ values, maximum $\mathrm{Tf}$ value was recorded for $\mathrm{Pb}(2.45)$ in $\mathrm{B}$. juncea with $100 \%$ PME concentration, which showed high mobility affinity of $\mathrm{Pb}$ being translocated from roots to leaves resulting in their greater accumulation and had the capability to tolerate higher levels of these metals. Thus, the use of PME with proper dilution (10\%) and metallic concentration in permissible limit can be used as biofertigant for the purpose of this crop.

\section{ACKNOWLEDGEMENT}

The University Grant Commission, New Delhi, India is acknowledged for providing the financial support in the form of UGC research fellowship (F.7-70/2007 BSR) to Dr. Chakresh Pathak.

\section{REFERENCES}

AOAC (1990) Official methods of Analyses. Method No. 975.03 metal in plants, AAS method, 15th ed. Association of Official Analytical Chemists, Inc., Arlington, p 42.

APHA (2005). Standard M ethods for the Examination of Water and Wastewater. American Public Health Association, 21st edition, Washington, DC.pp 1368.

Arora,M., Kiran, B., Rani, A., Rani, S., Kaur, B. and Mittal, M. (2008). Heavy metal accumulation in vegetables irrigated with water from different sources. F ood C hemistry, 111 (4) : 811-815.

Awashthi, S. K. (2000). Prevention of Food Adulteration Act no. 37 of 1954. Central and State rules as amended for 1999 (3rd ed.). New Delhi: Ashoka Law House.

Bharagava, R.N., Chandra, R. and Rai, V. (2008). Phytoextraction of trace elements and physiological changes in Indian mustard plants (Brassica nigra L.) grown in post methanated distillery effluent (PMDE) irrigated soil. Bioresour. Technol., 99: 8316-8324.

Chandra, R., Bhargava, R.N., Yadav, S. and Mohan, D. (2009). Accumulation and distribution of toxic metals in wheat (Triticum aestivum L.) and Indian mustard (Brassica campestris L.) irrigated with distillery and tannery effluents. J. Hazard. M ater., 162(2-3):1514-1521.

Chaturvedi, R. K. and Sankar, K. (2006). Laboratory manual for the physico-chemical analysis of soil, water and plant. Wildlife Institute of India, Dehradun. pp. 97.

Chopra, A. K. and Pathak, Chakresh (2012). Bioaccumulation and translocation efficiency of heavy metals in vegetables grown on long-term wastewater irrigated soil near Bindal river, Dehradun. Agric Res., DOI 10.1007/s40003-012-00168.

Chopra, A.K., Pathak, C. and Prasad G. (2009). Scenario of heavy metal contamination in agricultural soil and its management. J . A ppl. \& Nat. Sci., 1(1): 99-108.

Codex Alimentarious Commission (1984). Contaminants, J oint FAO/WHO Food standards Program (Vol. XVII, 1st ed.). Geneva: Codex Alimentarious.

Cui, Y.J., Zhu, Y.G., Zhai, R.H., Chen, D.Y., Huang, Y.Z., Qui, Y., Liang, J.Z. (2004). Transfer of metals from near a smelter in Nanning, China. E nviron. Int. 30, 785-791.

Gupta, N., Khan, D.K. and Santra, S.C. (2008) An assessment of heavy metal contamination in vegetables grown in wastewater-irrigated areas of Titagarh, West Bengal, India. Bull Environ Contam Toxicol., 80:115-118.

Gupta., S, Satpati, S., Nayek, S. and Garai, D. (2010) Effect of wastewater irrigation on vegetables in relation to bioaccumulation of heavy metals and biochemical changes. Environ M onit Assess., 165: 169-177. 
Harmanescu, M., Maria Alda, L., Maria Bordean, D., Gogoasa, I. and Gergen, I. (2011). Heavy metals health risk assessment for population via consumption of vegetables grown in old mining area; a case study: Banat County, Romania. Chemistry Central J ournal, 5:64.

Hati, K.M., Biswas, A.K., Bandyopadhyay, K.K. and Misra, A.K. (2007). Soil properties and crop yields on a vertisol in India with application of distillery effluent. Soil Till. Res., 92 (1-2): 60-68.

Ismail, B.S., Farihah, K. and Khairiah, J. (2005) Bioaccumulation of heavy metals in vegetables from selected agricultural areas. Bull. Environ. Contam. Toxicol., 74:320327.

Kabata-Pendias, A. and Pendias, H. (1992). Trace elements in soil and plants (2nd ed., p. 365). Boca Raton: CRC.

Kumar, V. and Chopra, A. K. (2012). Fertigation effect of distillery effluent on agronomical practices of Trigonella foenum- graecum L. (Fenugreek). Environ. M onit. Assess., 184:1207-1219.

Kumar, V. and Chopra, A. K. (2010). Influence of sugar mill effluent on physico-chemical characteristics of soil at Haridwar (Uttarakhand), India J ournal of Applied and Natural Science, 2 (2): 269-279.

Kumar, V.(2010). Effect of industrial effluent irrigation on agronomical characteristics of two leguminous crops, Phaseolus vulgaris (L.) and Vigna radiate (L.)," Ph.D. Thesis, Gurukula Kangri University, Haridwar.

Kumar, V., Chopra, A.K., Pathak, C. and Pathak, S. (2010). Agro-potentiality of paper mill effluent on the characteristics of Trigonella foenum-graecum L. (Fenugreek). New York Science J ournal, 3(5): 68-77.

Liss, S.N., Bicho, P.A. and Saddler, J.N. (1997). Microbiology and biodegradation of resin acids in pulp mill effluents: a minireview. Can. J. Microbiol., 43(7):599-611.

Malla, L. and Mohanty, B. K. (2005). Effect of paper mill effluent on germination of green Gram (Ph Roxb.) and growth behaviour of it's seedlings. J ournal of E nvironmental Biology, 26 (2) : 379- 382.

Mapanda, F., Mangwayana, E. N., Nyamangara, J. and Giller, K. E. (2005). The effect of long-term irrigation using waste water on heavy metal contents of soils under vegetables in Harare, Zimbabwe. Agriculture Ecosystem and Environment, 107 (2-3): 151-165.

Pathak, C., Chopra, A. K. and Srivastava, S. (2013). Accumulation of heavy metals in Spinacia oler acea irrigated with paper mill effluent and sewage. Environ M onit Assess., 185:7343-7352.

Rath, P., Pradhan, G. and Misra, M.K. (2011). Effect of distillery spent wash (DSW) and fertilizer on growth and chlorophyll content of sugarcane (Saccharum officinarum L.) plant. Recent Res. Sci. Technol., 3(4):169-176.

Sharma, R. K., Agrawal, M. and Marshall, F. M. (2007). Heavy Metals Contamination of Soil and Vegetables in Suburban Areas of Varanasi, India. Ecotoxicology \& Environmental Safety, 66 (2): 258-266.

Singh, A., Sharma, R.K., Agrawal, M., Marshall, F.M. (2010). Risk assessment of heavy metal toxicity through contaminated vegetables from waste water irrigated area of Varanasi, India. Tropical E cology, 51(2S):375-387.

Singh, P. (2007). Sequential anaerobic and aerobic treatment of pulp and paper mill effluent in pilot scale bioreactor. J ournal of Environmental Biology, 28(1) 77-82.

Singh, S. and Kumar, M. (2006). Heavy metal load of soil, water and vegetables in periurban Delhi. Environmental Monitoring and Assessment, 120 (1-3): 71-79.

Sinha, S., Singh, S. and Mallick. S. (2008). Comparative growth response of two varieties of Vigna radiata L. (var. PDM 54 and var. NM 1) grown on different tannery sludge applications: effects of treated wastewater and ground water used for irrigation. Environment Geochemistry \& Health 30: 407-422.

Smical ,A. Vasile, H., Oros, V., Jozsef J. and Elena, P. (2008). Studies of Transfer and Bioaccumulation of Heavy Metals from soil into lettuce. Environmental Engineering and Management J ournal, 7: 609-615.

Tewari, P.K., Batra, V.S. and Balakrishnan, M. (2009). Efficient water use in industries: Cases from the Indian agro-based pulp and paper mills. J ournal of Environmental M anagement, 90: 265-273.

Thompson, G., Swain, J., Kay M. and Forster, C.F. (2001). The treatment of pulp and paper-mill effluent: A review. Biores. Technol., 77 (3): 275-286.

Yang, X.E., Baligar, V.C., Foster, J.C. and Martens, D.C. (1997). Accumulation and transport of nickel in relation to organic acids in rye grass and maize grown with different nickel levels. Plant Soil, 196 :271-276.

Zheng, N., Wang, Q., Zhang, X., Zheng, D., Zhang, Z. and Znang, S. (2007). Population health risk due to dietary intake of heavy metals in the industrial area of Huludao City, China. Sci. Total Environ., 387: 96-104. 